\title{
Daily life in Vietnam: Common People's Financial Situation
}

\section{TSUKAHARA Nagaaki*}

It is said that the salary of Vietnamese workers, even those who work for foreign companies, is about US\$400-500 per month. Many people in Vietnam possess motorbikes, and these motorbikes will typically cost about US $\$ 1,000$. In addition, the price of land, at least in urban central areas, is said to be rather expensive in Vietnam. Real estate prices at the "Old Quarter," in the central part of Hanoi, is said to be equivalent to those in Ginza, Tokyo. The suburbs of Hanoi are undergoing a construction boom and most of the multistoried buildings are residential and/or condominium units, worth tens of millions yen, just like in Japan. In the street in Hanoi, I see many luxury cars, such as Benz, BMW, Lexus etc., rushing around. I hear that these cars are expensive much rather than when we buy them in Japan because of the imposition of $100 \%$ custom duty. Considering the number of these expensive goods and accommodations, it seems that not only the wealthy classes purchase them. If so, how people can purchase expensive goods, such as houses and/or cars as well as motorbikes, with small salary in Vietnam?

One answer is that those who have originally something expensive, such as real estate, sell it off, and buy a new one. Now in Vietnam is the time of "land and real estate bubble economy," it is said that quite a few people has profited through land speculation. In general, there is no system of payment in installments in Vietnam like in Japan. Many people transact with each other by paying lump-sum in cash even when purchasing expensive goods. In the case of real estate transaction, some people deal with gold instead of cash. In Japan, it is common to purchase expensive goods by the installment. I was very surprised to hear that in Vietnam the installment payment is not common for people who purchase expensive goods.

The other answer is that people in Vietnam occasionally use a commune's credit union/association, such as "Tanomoshiko" which used to be popular in Japan. "Tanomoshiko" is a kind of collective loan fund in which a number of persons agree to deposit a small sum each for immediate use of one of the group, who are chosen

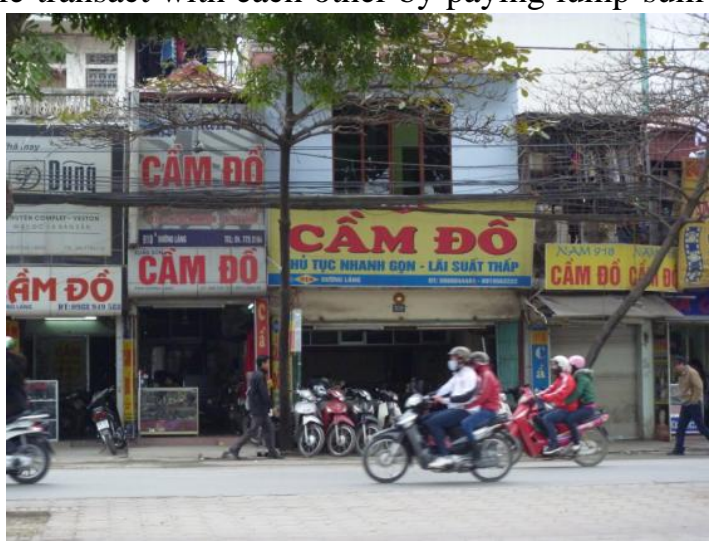

Cam Do (pawnshop) street in Hanoi by lottery. This had been used as people's finance/loan system form Kanakura-Era (1192-1333) until recently. For example, see "The Autobiography of Yukichi Fukuzawa," Translated by Eiichi Kiyooka, with a Foreword and Afterword by Albert Craig (Columbia University Press, 2007) pp.261-262.

In addition, there is an abnormally large number of pawnshops in Vietnam. For example, we can see dozens or thousands of pawnshops located on one street in a certain area. Motorbikes, cellular phones, etc., probably pawned, are displayed in the shop window or outside the front of the store. Although those who earn an honest dollar will seldom use a pawnshop, I hear that not only the poor but also thieves with stolen goods visit pawnshops. The pawnshops lend money at high-interest rates, similar to the consumer-finance loan sharks in Japan. The role of pawnshops in Vietnam is somewhat similar to Japan.

\footnotetext{
* The author is Coordinator/Lecturer of Japanese Law at the Nagoya University Research and Education Centre for Japanese Law in Hanoi University of Law.
} 